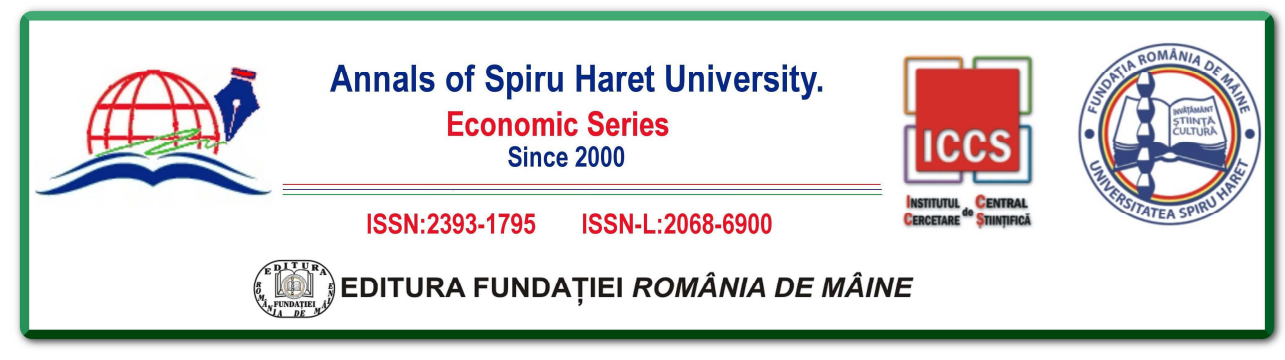

Issue 2/2018

\title{
PERSONAL INCOME TAX ADMINISTRATION IN THE RURAL COMMUNITIES (A STUDY OF SELECTED LOCAL GOVERNMENT AREAS IN OGUN STATE, NIGERIA)
}

\author{
Gbadegesin Babatunde ADEYEYE ${ }^{1}$, Adeleke Oluwafemi ADEOYE ${ }^{2}$, \\ Adeyemi Mobolaji ADEYEYE ${ }^{3}$ \\ 1 Department of Accounting, Faculty of Management Sciences, \\ University of Lagos, Nigeria, Phone: +2348037192416, E-mail: \\ tundeadeyeye2003@yahoo.com or gadeyeye@unilag.edu.ng \\ 2 Department of Accounting, Faculty of Management Sciences, \\ University of Lagos, Nigeria, E-mail: \\ adeleke.adeoye@ogunstaterevenue.com \\ 3 Department of Accounting, Faculty of Management Sciences, \\ University of Lagos, Nigeria, E-mail: ay_mj@yahoo.com
}

How to cite: ADEYEYE, G., ADEOYE, A., \& ADEYEYE, A. (2018). PERSONAL INCOME TAX ADMINISTRATION IN THE RURAL COMMUNITIES. A STUDY OF SELECTED LOCAL GOVERNMENT AREAS IN OGUN STATE, NIGERIA, Annals of Spiru Haret University. Economic Series, 18(2), 25-52, doi:https://doi.org/10.26458/1821

Abstract

The study examined the effectiveness of Personal Income Tax Administration in the rural communities, focusing on assessment and revenue collection methods, effectiveness and efficiency of Relevant Tax Authorities. 125 copies of questionnaire were administered on respondents. Descriptive statistics was used to analyse the opinions of key stakeholders directly connected with Direct and Minimum Tax Assessments in six selected Local Government Areas in Ogun State, Nigeria. Testing of the hypotheses for the study was done using both simple and multiple regression analysis. The 


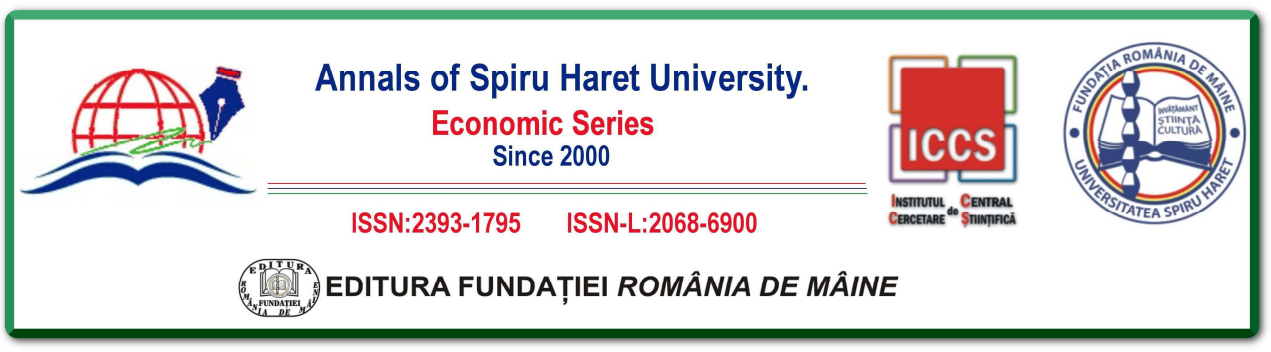

Issue $2 / 2018$

findings from the study indicate that tax assessment method significantly encourages voluntary enrolment into the tax net and that effective collection method adopted by the relevant tax authorities ensures optimal tax revenue collection. The study recommends that government should intensify its enlightenment programmes and to introduce awards for recognition of the best rural taxpayers.

Keywords: personal income tax; rural communities; tax administration; tax assessment; relevant tax authorities.

JEL Classification: D31

\section{INTRODUCTION}

\subsection{Background to the Study}

The Nigerian Tax Policy (2016) states that "tax is any compulsory payment to government imposed by law without direct benefit or return of value or a service whether it is called a tax or not" (p. 1). Payment of tax is regarded as a civic and patriotic responsibility of citizens which provides a regular major source of fund for government to defray its expenditure on social amenities, provision of infrastructures, security and safety of life and properties within and outside the country [Adeyeye, 2009, 2013; Angahar \& Alfred, 2012]. A good tax system is made up of the tax policy, tax laws and tax administration. These three elements of tax system are expected to interface to promote the attainment of the economic goal of the nation. The National Tax Policy (2016) provides the fundamental guidelines for the orderly development of the Nigerian tax system. The Policy is expected to achieve the following specific objectives among others: (i) guide the operation and review of the tax system; (ii) provide the basis for future tax legislation and administration; (iii) serve as a point of reference for all stakeholders on taxation; (iv) provide a benchmark on which stakeholders shall be held accountable; and (v) provide clarity on the roles and responsibilities of stakeholders in the tax system.

In an attempt to fulfil the above expectation, the national tax policy is expected to be in compliance with the principles of taxation which are the lubricants to effective tax system.

According to the Guiding Principles of Nigerian Tax System, all the existing and future taxes are expected to align with the following fundamental features: (i) 


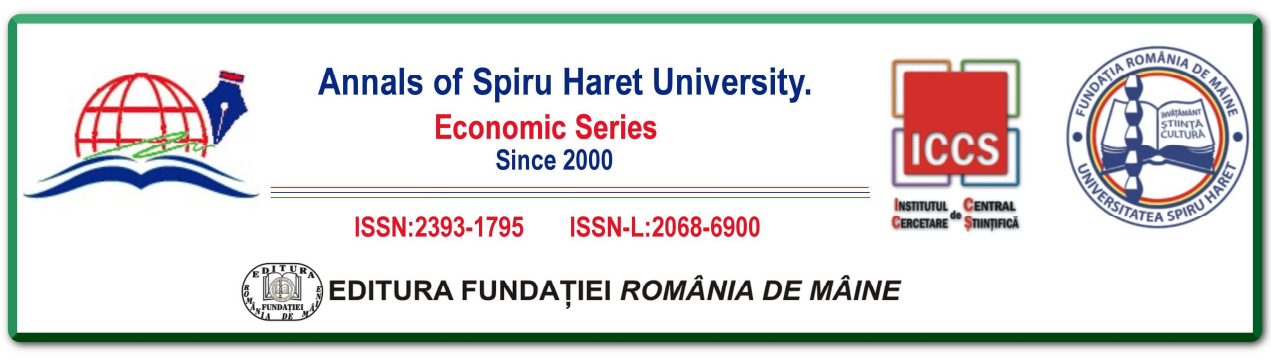

Issue 2/2018

Equity and fairness; (ii) Simplicity, certainty and clarity; (iii) Low compliance cost; (iv) Low cost of administration; (v) Flexibility; and (vi) Sustainability [National Tax Policy, 2016]. This is in consonant with Adam Smith cannons of taxation which emphasised that a good tax system must be based on equity, certainty, convenience, economy, simplicity, productivity and efficiency [Uremadu \& Ndulue, 2011].

Taxes are backed by laws. Tax Laws refer to the embodiment of rules and regulations relating to tax revenue and the various kinds of taxes in Nigeria. The assessment and collection of personal income tax in Nigeria is regulated by the Personal Income Tax Act (PITA) CAP P8 Laws of the Federation of Nigeria (LFN) 2004 as amended by the Personal Income Tax (Amendment) Act, 2011. The law provides that Personal income tax shall be collected by the various state governments through the State Internal Revenue Service (SIRS) which is the administrative arm of the State Board of Internal Revenue (SBIR), from individuals resident in the tax territory. Taxes from certain categories of individuals such as persons employed in the Nigerian Army, the Nigerian Navy, the Nigerian Air force, the Nigerian Police other than in a civilian capacity, officers of the Nigerian Foreign Services, residents of the Federal Capital Territory, Abuja (both employed and self-employed persons), a person resident outside Nigeria who derives income or profit in Nigeria are collected by the Federal Inland Revenue Service (FIRS) on behalf of the Federal Government [Joint Tax Board, 2012]. Even though the informal sector operators dominate the Nigerian economy, they do not see the need to pay tax, as to them, only the civil servants should pay tax on their earnings [Ayodele, 2006]. A number of authors have argued that assessing these informal sector operators to tax and collection of tax revenue from them is a herculean task and that the level of tax compliance is less than 27\% [Abiola, 2007], even though arguably, the informal sector makes up to $50 \%$ of the Nigerian economy (Civil Society Legislative Advocacy Centre (CSLAC), 2014).

\subsection{Statement of the Problem}

Administration of Personal Income Tax in the rural communities is the focus of this research project. A rural area is a geographic area that is located outside the cities and towns, often characterised by government neglect and poor infrastructural development. Previous studies have observed that of all the taxes, 


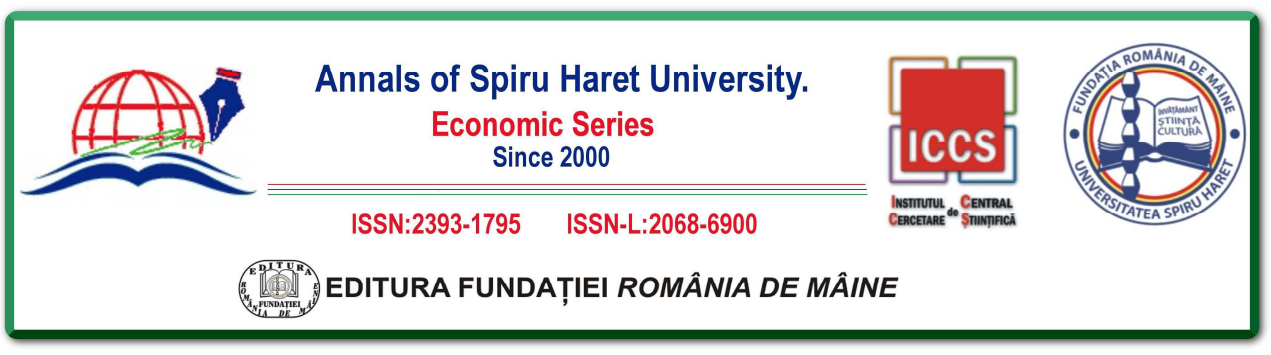

Issue $2 / 2018$

personal income tax has remained the most disappointing, non-performing, unsatisfactory and problematic in Nigeria tax system [Asada, 2005; Kiabel \& Nwokah, 2009; Nzotta, 2007]. A large number of the prospective taxpayers reside and work in the rural areas with difficult terrain and pay no tax at all on their earnings. A few others who are identified under direct assessment and minimum tax, pay tax on some earnings but fail to declare other additional sources of incomes. The peculiar nature of rural communities require that government should be up and doing in terms of provision of public goods and infrastructure. Akintoye and Tashie (2013) remarked that the peoples' willingness to pay tax is greatly influenced by their perception of the government's delivery. Angahar and Alfred (2012) explained that self-employed taxpayers are unincorporated individuals or body of individuals engaged in their own business either as a sole trader or in partnership. Such persons include individual contractors, traders, professionals, consultants, market men and women, artisans and all other entities that are not liable to tax under the Companies Income Tax Act (CITA), but under the Personal Income Tax Act (PITA). This means such persons are taxable on income accruing to them personally.

Adebisi and Gbegi (2013) observed that tax evasion and avoidance are problems that face every tax system; however, the Nigerian situation seems unique when viewed against the scale of corrupt practices prevalent in Nigeria. Under direct personal taxation as practiced in Nigeria, the major problem lies in the collection of the taxes, especially from the self-employed categorised as follows: professionals such as lawyers, doctors and accountants, to mention just three, artisans, traders, transporters and farmers. These individuals blatantly refuse to pay tax by reporting losses every year and live a lifestyle that is inconsistent with their reported income, which is usually unrealistically low for the nature of their businesses [Ayua, 1996]. Ayua (1996) opines that the tax system is grossly inadequate as it is characterized with tax evasion, avoidance and record falsifications which account for the consistent low tax yields.

The tax laws in Nigeria are complex and difficult for the common taxpayer to understand as many taxpayers are unaware of the existence of certain taxes. The problems associated with an enquiry into the tax administration in Nigeria seem to be numerous but it appears no studies have been comprehensively carried out to examine the system in a manner that attempts to relate the tax administration to tax 


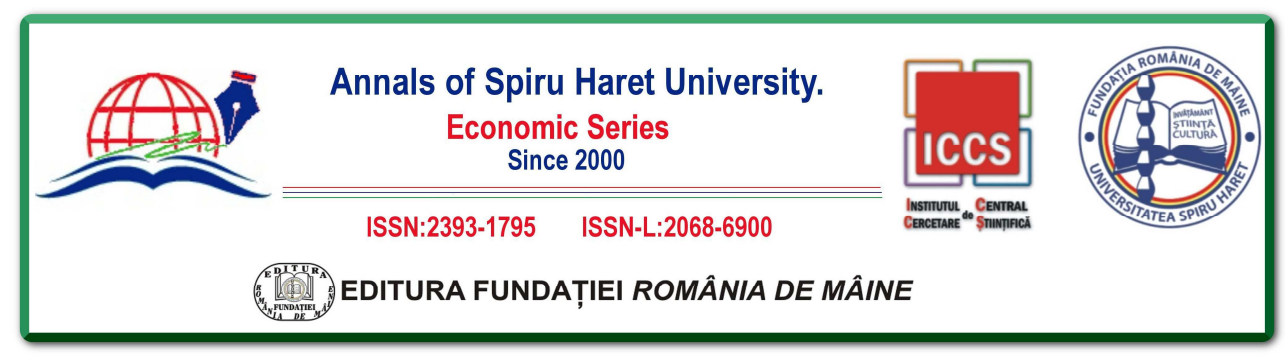

Issue 2/2018

laws and policies in Nigeria. This dearth of relevant literature on comprehensive analysis of tax administration, policies and laws in Nigeria seems to create a gap between what the people perceive to be reliable tax revenue administration and what it is in reality. This therefore necessitated this study in order to redress these anomalies.

\subsection{Aim and Objectives of the Study}

The aim of this study is to investigate the various constraints faced by the State tax authority in assessing and collecting taxes from the self-employed taxpayers in the rural communities and proffer solutions as regard strategies to be adopted by the State tax authority for expanding the tax net and to improve tax collection drive covering the self-employed. Consequently, the objectives of the study are to:

(i) Determine the extent to which the method of assessing personal income tax encourages voluntary enrolment into the tax net in the rural communities.

(ii) Investigate the effectiveness of methods used in the collection of personal income tax in the rural communities for optimum tax revenue.

(iii) Examine the extent to which the relevant tax authorities are effective and efficient in applying the personal income tax laws in the rural communities.

\subsection{Research Questions}

The study addressed the following research questions in line with the stated objectives.

(i) How does the method of assessing personal income tax in the rural communities encourage voluntary enrolment into the tax net?

(ii) How effective are the methods of collection of personal income tax in the rural communities for optimum tax revenue?

(iii) How effective and efficient are the relevant tax authorities in applying the personal income tax laws in the rural communities?

\subsection{Research Hypotheses}

The following null hypotheses are formulated for the study to answer the above research questions. 


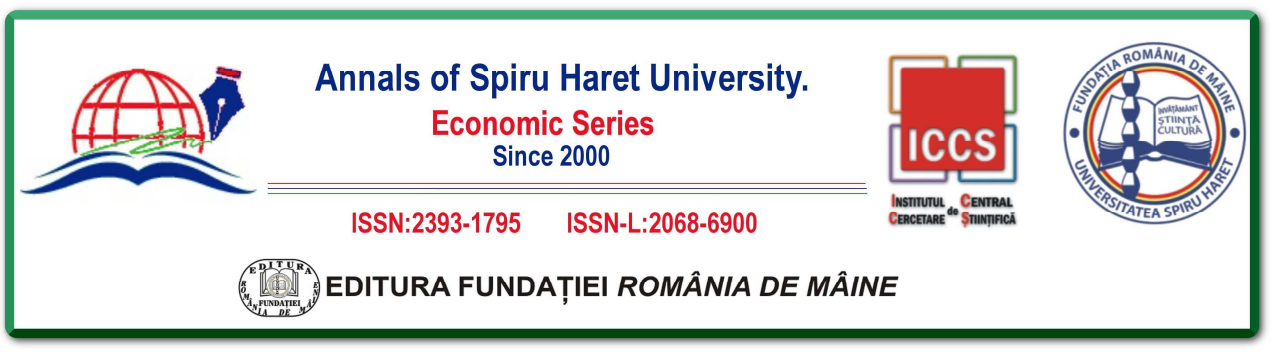

Issue 2/2018

$\mathbf{H}_{\mathbf{0 1}}$ : Personal income tax assessment method in the rural communities does not encourage voluntary enrolment into the tax net.

$\mathbf{H}_{02}$ : Personal income tax collection methods in the rural communities are not effective for optimal tax revenue.

$\mathbf{H}_{\mathbf{0 3}}$ : The relevant tax authorities are not effective and efficient in applying the personal income tax laws in the rural communities.

The study focused on personal income tax administration in the rural communities, with the study of six selected local government areas in Ogun State, Nigeria. The personal income tax examined was restricted to Direct Assessment (DA) and Minimum Tax (MT), being an area where tax assessment and collection are highly susceptible to tax evasion and avoidance in view of the status of the taxpayers as self-employed, nature of their business registration and geographical location of the rural communities, which is outside the city and towns.

\section{REVIEW OF RELATED LITERATURE}

\subsection{Conceptual Framework}

Evolution of Personal Income Tax Administration

The Income Tax Management Act (ITMA) 1961 was promulgated for the taxation of individuals. The main purpose of ITMA 1961 is to regulate the imposition of personal income tax throughout the Federation so that double taxation of incomes by the Federal Government and State Government will be avoided. The Act sets up a Joint Tax Board (JTB) which is charged with the responsibility of determining technical and other issues in which interests of those governments might otherwise be in conflict. Each government has sole jurisdiction to impose personal income tax on individuals resident or deemed to be resident in its territory, however, the 1961 Act does not seek to encroach upon the right of each government to decide upon the appropriate level of taxation of those individuals who under the provisions of the Act, fall within its jurisdiction. The Income Tax Management Act (ITMA) 1961 determines such questions as to what is taxable income, what deductions may be allowed against gross income to arrive at the taxable income and the period over which assessable income is to be determined. The above legislation (ITMA 1961) was later repealed and re-enacted as the Personal Income Tax Act (PITA) 1993 [Yerokun, 1997; Ariwodola, 2001]. 


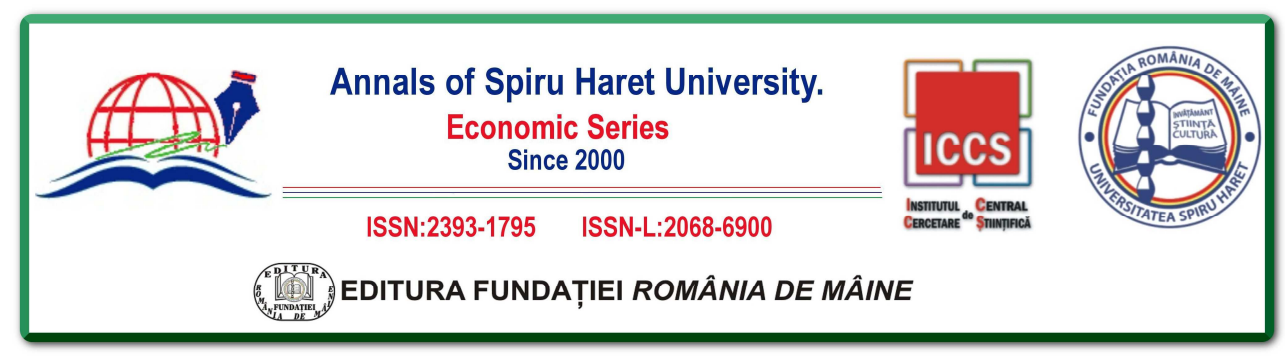

Issue 2/2018

The current law that governs the administration of personal income tax is the Personal Income Tax Act Cap. P8 LFN 2004 [as amended by Personal Income Tax (Amendment) Act, 2011] which imposes tax on incomes of individuals. It governs the whole process of assessment and collection of tax revenue, by the relevant tax authority. Personal income tax administration therefore is the whole process of tax assessment and collection of tax revenue by the tax officials. In order to achieve this objective, the Act authorized the State Government through the State Internal Revenue Service to collect personal income tax from individuals taxpayers resident in the State, and Federal Government through the Federal Inland Revenue Service to collect personal income tax from members of the Armed Forces, members of the Nigerian Police Force, residents of the Federal Capital Territory, Abuja, staff of the Ministry of Foreign Affairs and non-resident individuals.

\section{Definition of Rural Communities}

These are areas and settlements that are geographically located outside cities and towns; and are sparsely populated, in which people farm or depend on natural resources, including villages and small towns that are dispersed through these areas (Government of South Africa, 1997). Rural communities in the Nigeria context are characterized by poor infrastructural development, bad roads networks and neglect in the provision of basic amenities such as pipe-borne water, electricity, schools and healthcare services to mention just a few.

Taxpayers in the rural communities are usually assessed to tax through direct taxation. Direct taxation could either be by way of direct assessment or minimum tax.

\section{Direct Assessment}

This relates to taxes that are levied on the incomes, gains or profits of individual and business firms, and which are actually paid by the person or persons on whom it is legally imposed. Self-employed who register their business names with the Corporate Affairs Commission and also with the tax authority that are able to produce records of their business transactions, for instance, legal practitioners, accountants and other professionals, partners in a partnership business and sole proprietors are being assessed to tax through this medium.

\section{Minimum Tax}




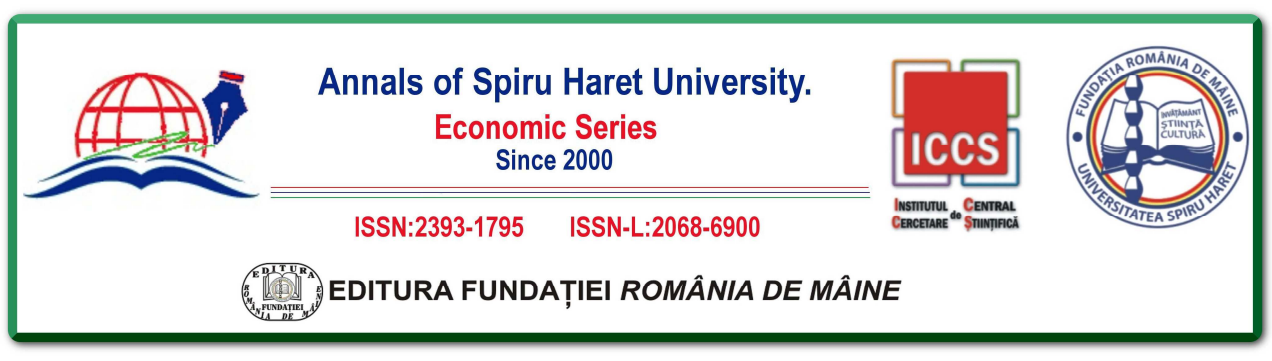

Issue 2/2018

The Personal Income Tax (Amendment) Act, 2011, states that "where after all deductions allowable under this Act the individual has no chargeable income or where the tax payable on the chargeable income of that individual is less than 1 per cent $(<1 \%)$ of the total income of that individual, the individual shall be charged to tax at the rate of 1 per cent (1\%) of his total income" [Section 37, Personal Income Tax (Amendment) Act, 2011]. Certain categories of self-employed such as the artisans, traders, farmers, motor-cyclists, drivers and transporters that have not registered their businesses and do not keep records of their business operations are being assessed to tax through this method.

\section{Relevance of Tax Administration in Rural Communities}

Income tax is one of the major important sources of revenue accruable to the government.

It is a source to think of in both the state and federal governments' budgets. The taxes collected do come back to the taxpayers in the form of social amenities provided by the government. However, the peculiar nature of the rural communities makes the administration of personal income tax more problematic. Mengesha and Ashebir (2013) observed that these taxpayers are most problematic category of taxpayers and are considered as hard-to-tax group. This is due to the fact that these taxpayers pay taxes at fixed rate/amount on the income estimated by the tax authority rather than declaring their income by themselves. Their daily income is estimated by 'best of judgment' assessment and the taxpayers have little room to express their view so that frequent friction is observed in this area [Mengesha \& Ashebir, 2013].

\section{Tax Assessment Procedure}

Tax assessment underpins tax collection, therefore a good tax system involves tax policy, tax laws to impose the tax, system of administration and efficient and effective method to assess and collect the tax revenue. Assessment procedure is not only determining tax liabilities which the taxpayers should pay to the tax authorities on the taxable income in case of income tax, but also knowing who should be on the tax net and which income should be subjected to tax liabilities. According to Barkoczy (1999), an assessment crystallizes the liability to pay tax and determines the time at which tax is due. Taxpayers are also entitled to object to assessment with which they are dissatisfied in accordance with the 


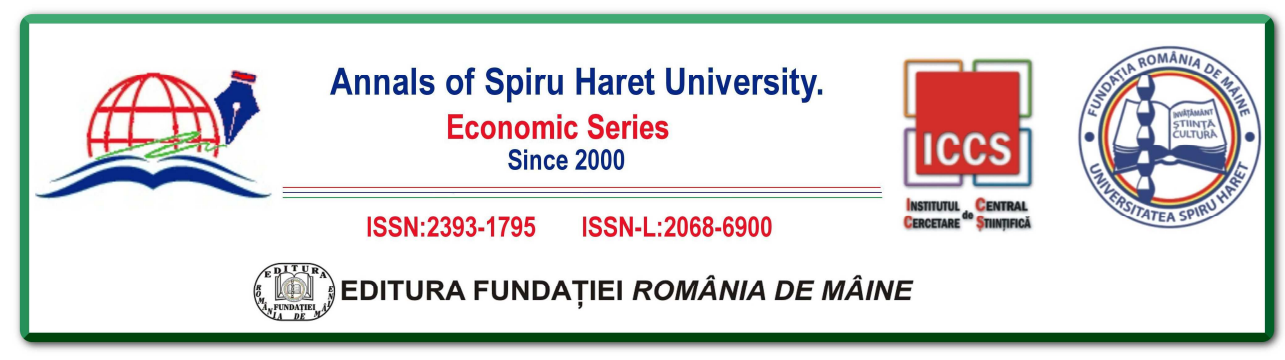

Issue 2/2018

procedure laid down by the country's legislation.

\section{Types of Assessments/Forms of Assessment}

There are three main types of assessments and these are Original or Initial Assessment, Revised or Amended Assessment and Additional Assessment. These types of assessments are based on the circumstances of the taxpayer concerned. The forms of assessment include Provisional Assessment, Best of Judgment (BOJ) Assessment and Self-Assessment.

\section{Allocation of Tax Powers in Nigeria}

In order to address the challenges of multiple taxation in Nigeria, Taxes and Levies (Approved List for Collection) Act 1998 was enacted. Part I of the Act contains taxes to be collected by the Federal Government, Part II consists of taxes and Levies to be collected by the State Government, while Part III contains taxes and levies to be collected by the Local Government.

\section{Problems Associated with Tax Assessment in the Rural Communities}

(i) Identification of the person to be assessed. Due to the poor terrain of the rural areas, non-existing method of house numbering and the very low degree of honesty, most taxable persons hide from tax authorities, and if possible would give fake addresses to conceal their identity. Many rural taxpayers do their business without any registration or any fixed addresses. It is therefore difficult to track down such persons for tax purposes.

(ii) Identifying income for tax purpose. The ascertainment of total income tax in most of the time proved difficult, for the simple reason that majority of the rural taxpayers do not keep records of their business transactions. Rural communities' taxpayers often flout notices to file return of income forms and either they fail to render any returns at all or even when they do, they render virtually useless returns, in the pretext that they are illiterates or do not know what to do.

\section{Tax Collection and Payment in the Rural Communities}

The tax charged by any assessment which is not or has not been the subject of an objection or appeal shall be payable within the stipulated time by the law [Soyode \& Kajola, 2006]. The collection process is expected to be done through the banks in order to block leakages. However, this has not been the case, in view 


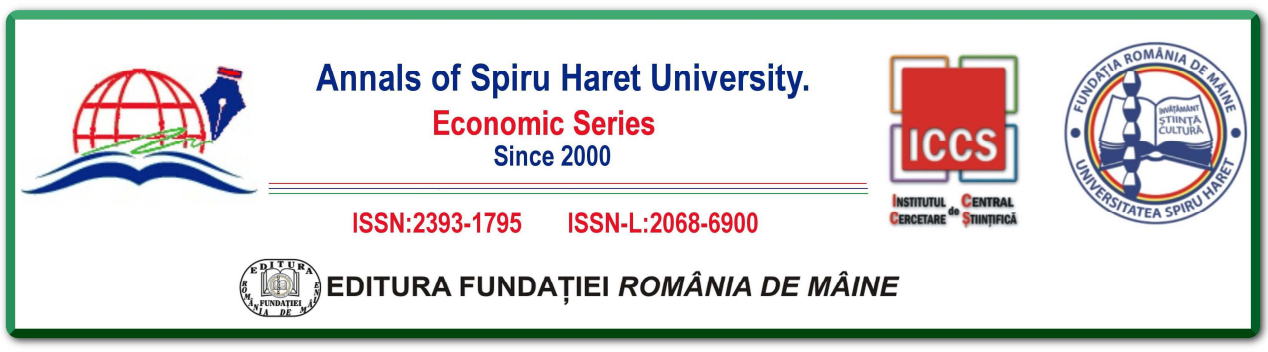

Issue 2/2018

of various challenges confronting both the taxpayers and tax officials as there is tendency for collusion, thereby depriving government access to full recovery of tax revenue. Hence the following constraints are identified:

i. Non-availability of banks in the rural areas to effect collection, due to high cost of collection to be incurred both by the bank and the tax authority.

ii. Distance between the available bank in the city and the rural communities in most cases are far and this may discouraged the taxpayers, thus they develop non-compliance attitude.

iii. Non-availability of other mode of tax payments that can make it convenient for the taxpayer to perform his/her civic responsibility.

iv. Acceptance of cash from the taxpayers by the tax officials under the pretence of rendering assistance to the taxpayers; which eventually ends in their private pockets.

Challenges of Relevant Tax Authorities in the Rural Communities

There is the operating arm of the State tax authority in the rural communities that is responsible for the administration of Personal Income Tax Laws. This body is made up of tax officials with adequate knowledge in the field of taxation. However, the following still constitute great challenges to tax administration in the rural communities.

(i) Dearth of Experienced and Qualified Personnel/Administrative Challenge. Lack of experienced and adequate number of personnel to manage the various relevant tax authorities hinders the effective tax administration in the rural communities. Majority of the State tax authorities are poorly staffed both in terms of quality and quantity of staff.

Leyira, Chukwuma and Asian (2012) consider the paucity of administrative capacity as a major impediment to the government in its attempts to raise revenue in Nigeria. The predominance of support staff in a professionally inclined agency like the State tax authority does not augur well for the effective and efficient tax revenue collection.

(ii) Inadequate Penalties/Absence of Enforcement/Compliance Challenge. In Nigeria, the penalties for non-compliance with relevant tax provisions are too lenient to compel the self-employed to pay tax. There is also a general lack of enforcement of existing penalties. Low penalties, sometimes ridiculous for tax defaulters do not serve as deterrent for others. They are also not strict enough to 


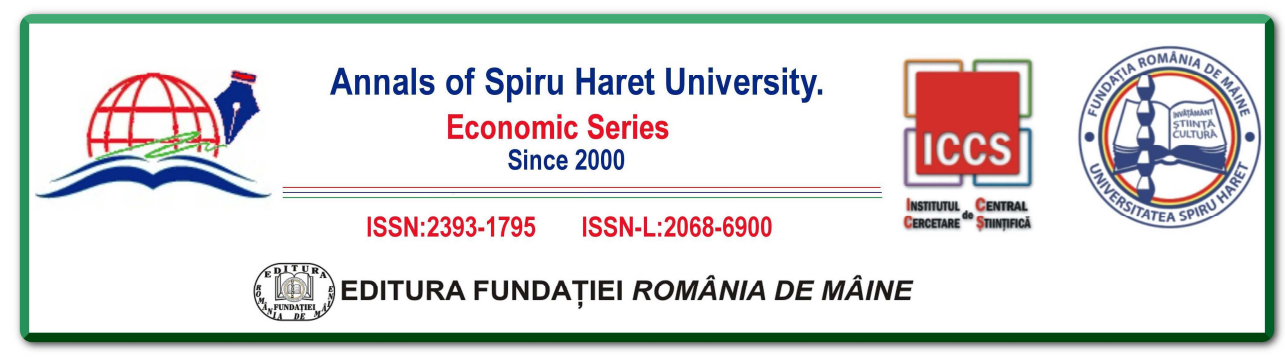

Issue 2/2018

encourage compliance. However, the recent Personal Income Tax (Amendment) Act, 2011 has taken good care of that, but how far it will be successful in the cause of implementation left much to be desired.

(iii) Attitudinal Problem. Most people do not know that it is part of their civic duties or responsibilities to pay tax and except for a few enlightened individuals, corporate organisations and salaried employees whose income are subjected to tax, taxpayers in the rural areas exhibit their nonchalant attitude towards payment of tax and therefore, do not regularly pay tax or not eager to pay tax at all.

(iv) Cumbersome Process of Payment/Low Image of Tax Officials. The procedure for paying certain taxes are too cumbersome and do not encourage prompt payment of tax by payers. In some instances they go scot free by bribing tax officials. The image of a tax man is that of a corrupt person. They are seen in the eyes of the public as not only corrupt but also lacking in personal integrity.

(v) Challenge of Multiple Taxes. Multiple taxation occurs where the tax, fee or rate is levied on the same person in respect of the same income by more than one state or local government Council [Abiola, 2012].

In a federal system of government, it is typical to have federal, state and local government taxes. However, according to the National Tax Policy (2016), "taxes similar to those being collected by a level of government should not be introduced by the same or another level of government. The federal, state and local governments shall ensure collaboration in harmonizing and eliminating multiple taxation" (p. 4). It is worthy of note that multiple taxation is still a challenge in the rural communities in Nigeria.

(vi) Lack of Public Enlightenment. Most of the self-employed taxpayers do not know what tax to pay, when to pay, who to pay to, where to pay and what relief and allowances they are entitled to. Government is faulted here because a good tax system should be certain and easy to administer. It is the responsibility of government at all levels to educate the public on their responsibility with respect to tax at all times.

(vii) Level of Corruption. Some tax officials collude with would be taxpayers to defraud the government of her taxes. A large chunk of tax revenue that is supposed to come into government coffers ended up in private pockets, thus compounding the problems of government's inability to provide the basic infrastructure needed for the orderly development of the society.

(viii) Autonomy of State Internal Revenue Service. For revenue boards to achieve the much desired level of efficiency and effectiveness; and consequently 


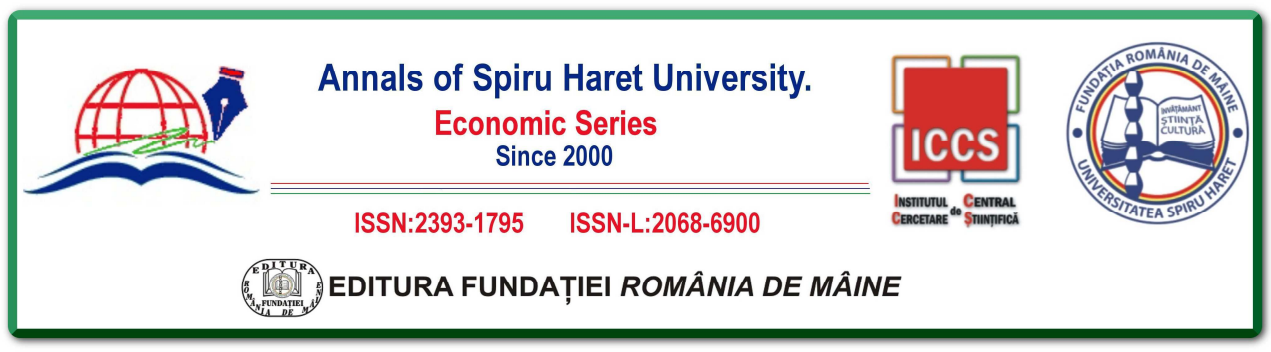

Issue 2/2018

achieve set goals, there must be financial and administrative autonomy without any form of undue direct or indirect interference from government. In essence, without full autonomy, tax administration will suffer setbacks, because initiative would give way to status bureaucracy [Mustapha, 2006].

\subsection{Theoretical Framework}

The study could be anchored on a number of theories. However, this study is based on two theories which are: (i) The Ability to pay theory; and (ii) The Benefits theory.

\section{The Ability to Pay Theory}

The ability-to-pay approach stipulates that the taxation should be levied according to an individual's ability to pay and that public expenditure should come from "him that hath" instead of "him that hath not" [Eftekhari, 2009, as reported by Adebisi \& Gbegi, 2013]. This is indeed the basis of 'progressive tax,' as the tax rate increases by the increase of the taxable amount. This principle is indeed the most equitable tax system, and has been widely used in industrialized economies. The usual and most supported justification of ability to pay is on grounds of sacrifice. Taxes paid are seen as a sacrifice by taxpayers, which raise the issues of what the sacrifice of each taxpayer should be and how it should be measured [Adebisi \& Gbegi, 2013].

\section{The Benefits Theory}

Under the benefit theory tax levels are automatically determined, because taxpayers pay proportionately for the benefits they receive from the government. In other words, the individuals who benefit the most from public services pay the most taxes. The benefit theory has a modern version, known as the "voluntary exchange" theory [Adebisi \& Gbegi, 2013].

\section{Conceptual Model}

Based on the various efforts by authors and researchers, this current study conceptualised the following model of how ability to pay and benefits of tax would influence efficient and effective tax administration in Ogun State, Nigeria. 


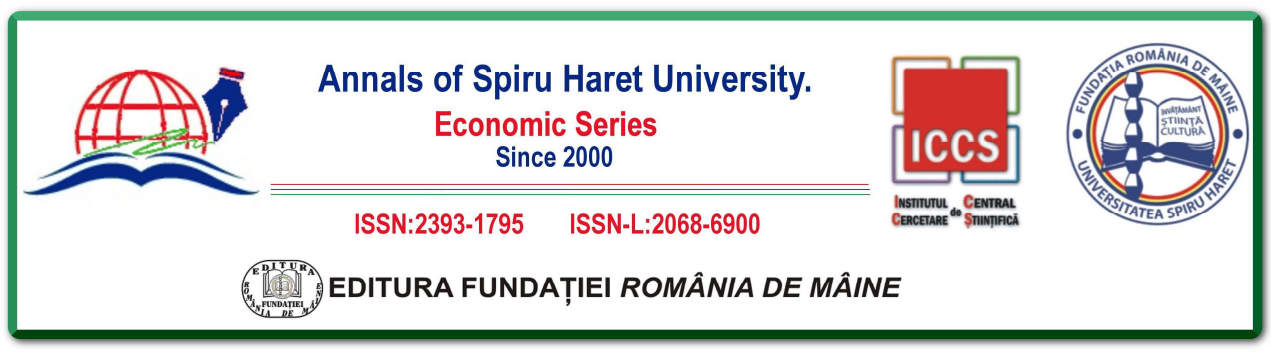

Issue 2/2018

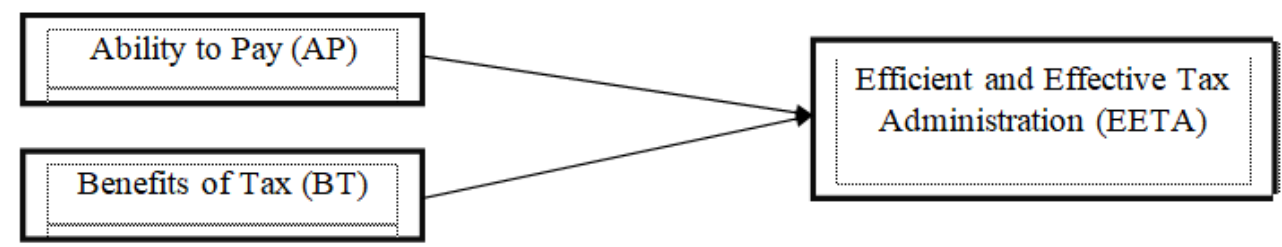

Figure no. 1. Conceptual Model for Efficient and Effective Tax Administration Source: Authors' Design, 2017

$\mathrm{EETA}=\beta_{0}+\mathrm{AP}+\mathrm{BT}+\varepsilon$

Where:

EETA $=$ Efficient and Effective Tax Administration

AP = Ability to pay

BT $=$ Benefits of tax

$\beta_{0} \quad=$ Coefficient

$\varepsilon=$ Error term

In view of the various issues dealt with in the previous discussions, it could be concluded that many standards and parameters can be used to assess Personal Income Tax Administration in the rural communities. "Ability to pay" is based on simple, clear and understandability of assessment, both to those who must apply them and those who are subject to them [Adebisi \& Gbegi, 2013]. This will most likely enhance efficient and effective tax administration. It is envisaged that "benefits of tax" in terms of delivery of social services, provision of merit and public goods which are urgently required in the rural communities will most likely encourage voluntary compliance, once the taxpayers can see how the government is judiciously applying their taxes.

Relevance of Personal Income Tax (Amendment) Act, 2011 to Direct Taxation in the Rural Communities

Personal Income Tax (Amendment) Act, 2011 was enacted to amend the Personal Income Tax Act, Cap. P8. LFN, 2004. No fewer than 41 items, including amendments to Cap.P8 LFN, 2004, 36 sections, First Schedule, Third Schedule, Sixth Schedule and Short Title of the old PITA law were reviewed. The new Act 


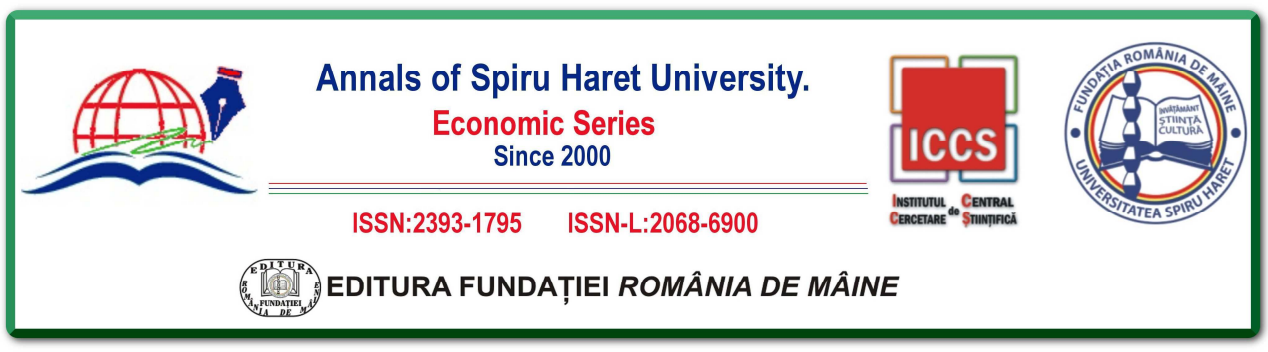

Issue $2 / 2018$

also provides more disposable income to the lower income earners following the amendment of the income Tax Table and adjustments in the applicable income tax incremental bands, which brings it in line with current income levels. The Act also simplified the compliance processes by consolidating the reliefs and allowances stipulated in the Act and lowering the burden on low income earners as well as widening the tax base by bringing in a huge number of potential taxpayers, especially in the informal sector, into the tax net. The Personal Income Tax (Amendment) Act, 2011 removes the obsolete, unrealistic and out-dated reliefs and allowances associated with the former Act, replacing them with enhanced consolidated reliefs and allowances. The Table below shows the current Personal Income Tax Rates.

Table no. 1. Tax Rate from 2011 to Date

\begin{tabular}{|l|l|l|l|l|c|}
\hline Table & $\begin{array}{l}\text { Chargeable } \\
\text { Income }\end{array}$ & Rate & Tax & $\begin{array}{l}\text { Cumulative } \\
\text { Income }\end{array}$ & $\begin{array}{l}\text { Cumulative } \\
\text { Tax }\end{array}$ \\
\hline & \multicolumn{1}{|c|}{} & $\%$ & & & \multicolumn{1}{c|}{} \\
\hline First & $300,000.00$ & 7 & $21,000.00$ & $300,000.00$ & $21,000.00$ \\
\hline Next & $300,000.00$ & 11 & $33,000.00$ & $600,000.00$ & $54,000.00$ \\
\hline Next & $500,000.00$ & 15 & $75,000.00$ & $1,100.000 .00$ & $129,000.00$ \\
\hline Next & $500,000.00$ & 19 & $95,000.00$ & $1,600,000.00$ & $224,000.00$ \\
\hline Next & $1,600,000.00$ & 21 & $336,000.00$ & $3,200,000.00$ & $560,000.00$ \\
\hline Above & $3,200,000.00$ & 24 & & & \\
\hline
\end{tabular}

Source: Personal Income Tax (Amendment) Act, 2011

\section{RESEARCH METHODS}

The population of this study consists of all rural taxpayers who are assessed to tax payment on direct assessment and minimum tax platform and all tax officials in various relevant tax authorities throughout the twenty (20) local government areas of Ogun State, Nigeria. Substantial numbers of these target rural taxpayers are categorized as Professionals (e.g., lawyers, doctors, accountants), Artisans, Traders, Transporters and Farmers. The study made use of both primary and secondary sources of data. The study adopted the survey research design through the use of structured questionnaire (on a 5-point scale) for gathering the primary data because 


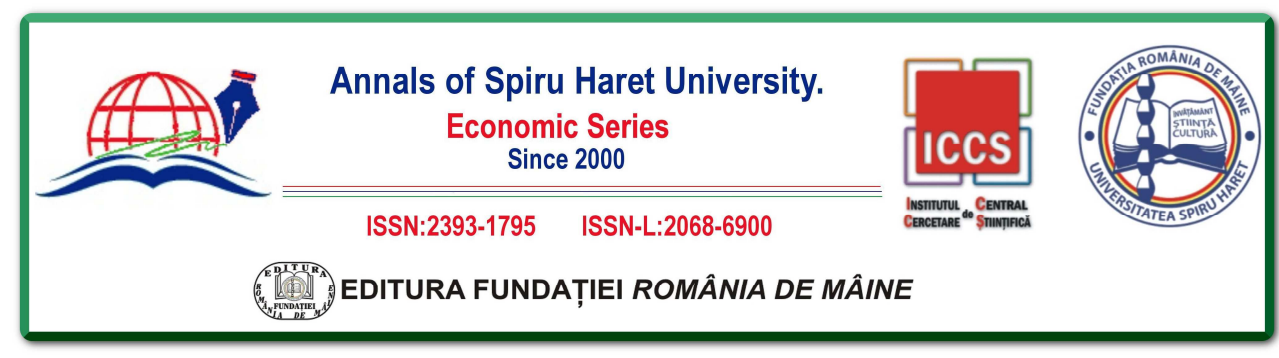

Issue 2/2018

of its ability to view comprehensibly and in detail the major questions raised in the study. This study relied on the twenty (20) local governments areas in Ogun State from where a total number of six (6) were selected. This is $30 \%$ of the local governments in Ogun State. It has been argued that the main purpose of a sample is how well it represents the characteristics of the population it purports to represent [Emory \& Cooper, 2003]. Out of the thirty-four (34) existing operational relevant tax authorities, being maintained by the Ogun State Internal Revenue Service, twelve (12), which represents approximately $35 \%$ of the relevant tax authorities were spread across the six (6) selected local government areas for this study (Central Department of Statistics, Ogun State internal Revenue Service, 2014).

The selection of the six local governments was based on convenience sampling, using stratified random sampling method which ensures the representation of sub-groups within a population based on their proportion or characteristics in that population. In doing this, number tags were attached to each of the 20 local government areas in Ogun State, for identification and the six (6) were randomly picked as representatives of the entire local government areas, thereby giving opportunity of being selected to all the twenty (20) local government areas. This approach minimises bias and simplifies analysis of results. The six (6) local governments selected on simple random basis are considered as appropriate and adequate for this study. The selected local government areas are: Ewekoro, Ijebu-East, Ikenne, Obafemi-Owode, Sagamu and Yewa-South Local Government Areas. Thus, a sample size of twenty (20) respondents were randomly selected from each of the six (6) selected local government areas totalling one hundred and twenty (120) taxpayers and three (3) tax officials (comprising Tax Office Manager, Direct Assessment Officer and Minimum Tax Assessment Officer) randomly selected from each of the twelve (12) relevant tax authorities mentioned above, making a total of thirty six (36) tax officials. In all, one hundred and fiftysix (156) respondents were surveyed. The twelve (12) Ogun State Internal Revenue Service tax offices are located in the following rural communities: Itori, Ogbere, Ikenne, Iperu, Owode-Egba, Ibafo, Adigbe, Isheri, Sagamu, Ogijo, Ilaro and Owode-Yewa. (Central Department of Statistics, Ogun State Internal Revenue Service, 2014).

A number of researchers have suggested appropriate sample sizes to be at least 30 and need not be larger than 500 based on an analysis of acceptable confidence levels in behavioural research studies [Roscoe, 1975; Industrial/ 


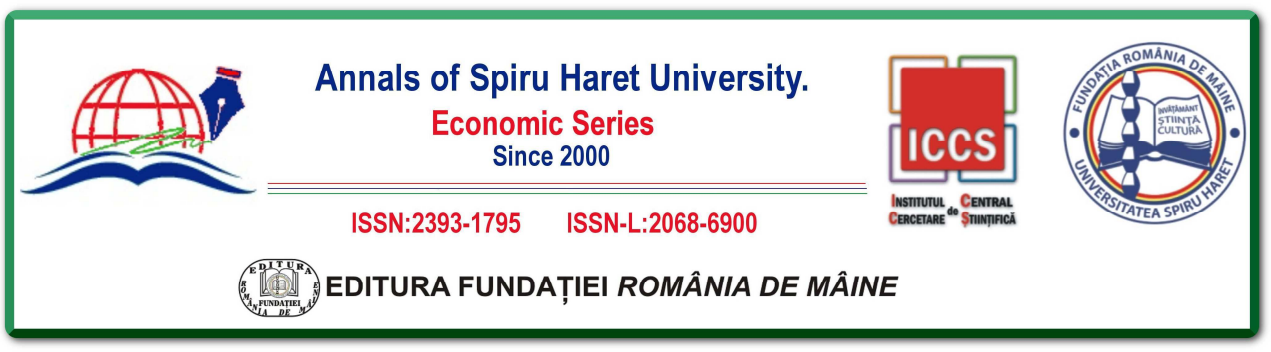

Issue $2 / 2018$

Organizational Solution, 2010]. Thus the sample size of one hundred and fifty-six (156) respondents randomly selected for this study is considered to be appropriate and adequate. The secondary sources of data included research journals, articles, textbooks and internet facilities. Basically, for this research, the dependent variable is the tax revenue generation from the rural communities, while Personal Income Tax Administration constitutes the independent variable. To this effect, the variables listed below are operationalized.

Simple regression analysis was used to determine the amount of tax revenue generation from the rural communities (dependent variable) which can be associated with changes in the value of each of the components of the independent variables (Personal Income Tax Administration). For the purpose of his study, these components are the Assessment method, Collection methods and Relevant Tax Authority.

\section{Model Specification}

The three independent variables can be modelled against the dependent variables as follows:

Model 1:

$\mathrm{y}_{1}=\mathrm{b}_{0}+\mathrm{b}_{1} \mathrm{x}_{1}+\varepsilon$

Where:

$\mathrm{y}_{1} \quad=$ Voluntary enrolment

$\mathrm{x}_{1}=$ Tax assessment method

$\mathrm{b}_{0}, \mathrm{~b}_{1}=$ Regression coefficient

$\varepsilon \quad=$ Error term
Model 2:

$\mathrm{y}_{2}=\mathrm{b}_{0}+\mathrm{b}_{2} \mathrm{x}_{2}+\varepsilon$

Where:

$\mathrm{y}_{2} \quad=$ Optimal tax revenue

$\mathrm{x}_{2}=$ Tax collection methods

$\mathrm{b}_{0}, \mathrm{~b}_{2}=$ Regression coefficient

$\varepsilon=$ Error term

\section{Model 3:}

$\mathrm{y}_{3}=\mathrm{b}_{0}+\mathrm{b}_{3} \mathrm{x}_{3}+\varepsilon$

Where:

$\mathrm{y}_{3} \quad=$ Personal Income Tax Act (PITA) Application

$\mathrm{x}_{3}=$ Effective and Efficient Relevant Tax Authority (RTA)

$\mathrm{b}_{0}, \mathrm{~b}_{3}=$ Regression coefficient

$\varepsilon=$ Error term 


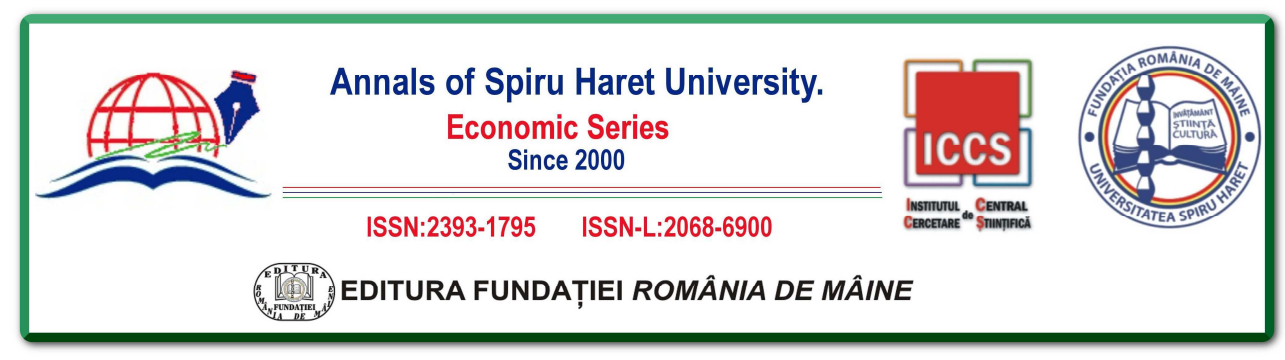

Issue 2/2018

Index of Personal Income Tax Administration, that is, Assessment method, Collection methods and Relevant Tax Authority represented by $\mathrm{x}_{1}, \mathrm{x}_{2}$ and $\mathrm{x}_{3}$ respectively are the independent variables. The $\mathrm{x}_{1}$ which is the first independent variable is the tax assessment method which is a major part of setting the expected target of tax revenue. That is, it reflects the expectation of the relevant tax authorities in terms of financial implication, since there can never be collection without assessment. The $\mathrm{x}_{2}$ is the tax collection methods, which can be regarded as vital turning point in ensuring that all tax revenue, actually get into government account; ensures total blockage of leakages and optimal tax revenue collection. The $\mathrm{x}_{3}$ is the relevant tax authorities which ensure policy implementation procedures and mechanisms for enforcement whenever there is non-compliance with the relevant tax laws.

The model specification above was specified to test the main effect of each independent variable on the dependent variable. The hypotheses 1-3 were further examined through multiple regression analysis using the multiple regression model shown below:

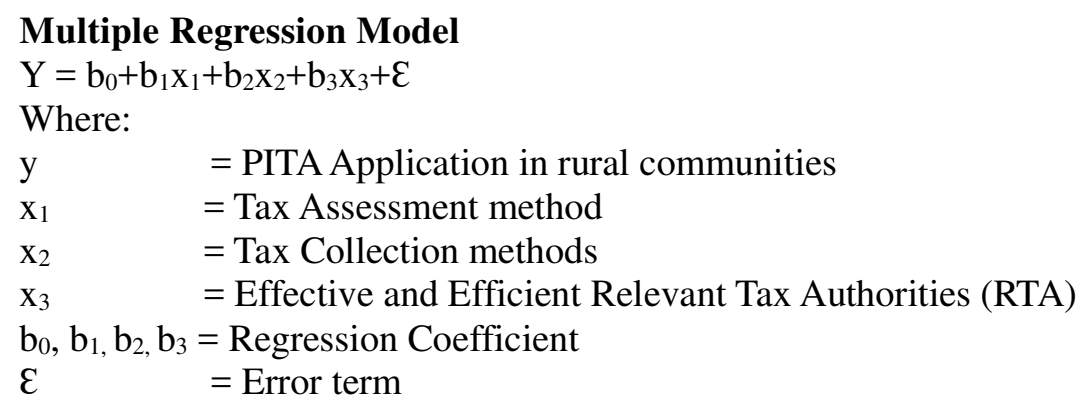

This study made use of both descriptive and inferential statistics. Descriptive statistics such as frequencies and percentages were used to present the demographic analysis of the respondents and also information relating to both the dependent and independent variables used for the study. Tests of hypotheses were carried out using Pearson's correlation and regression analysis with the aid of the Statistical Package for Social Sciences (SPSS) Version 20.00.

\section{DATA ANALYSIS AND PRESENTATION OF RESULTS}




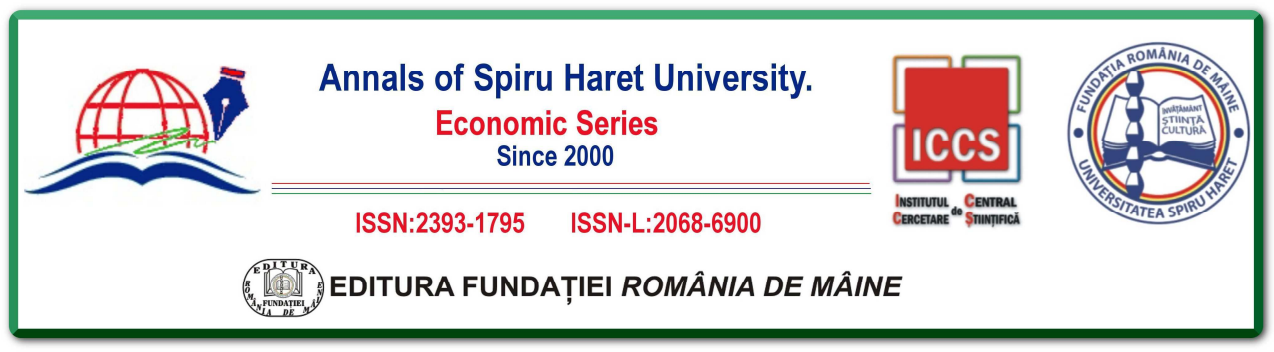

Issue 2/2018

Presentation of Demographic Variables of the Sample

The demographic characteristics of the respondents relating to variables such as category, educational qualification, age, gender and marital Status are represented in Table 2 using simple percentages.

Table no. 2. Demographics for All Respondents $(n=125)$

\begin{tabular}{|l|l|c|c|c|}
\hline Variable & Response & Frequency & $\begin{array}{c}\text { Valid } \\
\mathbf{\%}\end{array}$ & $\begin{array}{c}\text { Cumulative } \\
\mathbf{\%}\end{array}$ \\
\hline Age of the respondents (Years) & $20-40$ & 40 & 32.0 & 32.0 \\
\hline & $41-60$ & 55 & 44.0 & 76.0 \\
\hline & 61 \& above & 30 & 24.0 & $\mathbf{1 0 0}$ \\
\hline Gender of the respondents & Male & 81 & 64.8 & 64.8 \\
\hline & Female & 44 & 35.2 & $\mathbf{1 0 0}$ \\
\hline Marital Status of respondents & Single & 37 & 29.6 & 29.6 \\
\hline & Married & 65 & 52.0 & 81.6 \\
\hline & Divorced & 15 & 12.0 & 93.6 \\
\hline & Widow & 8 & 6.4 & $\mathbf{1 0 0}$ \\
\hline Educational qualification & None & 31 & 24.8 & 24.8 \\
\hline & Pry Sch. Cert & 24 & 19.2 & 44.0 \\
\hline & SSS Cert. & 30 & 24.0 & 68.0 \\
\hline & B.Sc./HND & 18 & 14.4 & 82.4 \\
\hline & M.Sc./MBA & 11 & 8.8 & 91.2 \\
\hline & Professionals & 11 & 8.8 & $\mathbf{1 0 0}$ \\
\hline Categories of the respondents & Professionals & 15 & 12.0 & 12.0 \\
\hline & Artisans & 19 & 15.2 & 27.2 \\
\hline & Traders & 23 & 18.4 & 45.6 \\
\hline & Farmers & 18 & 14.4 & 60.0 \\
\hline & Transporters & 20 & 16.0 & 76.0 \\
\hline & Tax Officials & 30 & 24.0 & $\mathbf{1 0 0}$ \\
\hline & \multicolumn{2}{|l}{}
\end{tabular}

Source: Authors' Survey, 2017 


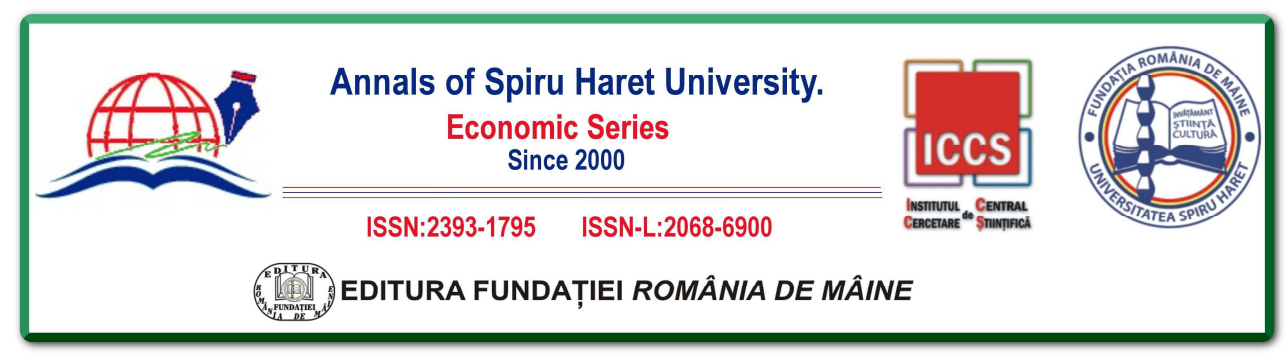

Issue 2/2018

Examination of Key Variables of Personal Income Tax Administration and Rural Communities

The aim is to investigate the relationship and influence that the variables have on each other. The tests were carried out at, 0.05 level of significance. The decision to accept or reject the null hypothesis is based on the p-value, the decision rule which states that when the p-value is less than the level of significance, the alternative hypothesis should be accepted but when the p-value is higher than the level of significance, the null hypothesis should be accepted. NB: Tables 3, 5, 7 and 10 are well explained but not presented in the body of the paper in order to optimise the maximum pages allowed by the Journal.

Research Question 1: How do the methods of assessing Personal Income Tax in the rural communities encourage voluntary enrolment into the tax net?

In order to answer the research question one (1), questionnaire items 6, 7, 8 and 9, were as analysed in Table 3 (not shown here). From the Table 3 (not shown here), it was observed that $54.4 \%$ of the sample disagrees with the opinion that the method of assessment is unfair and inefficient, though $36 \%$ said that the tax assessment method is unfair and inefficient, while the remaining 9.6\% of the sample were undecided in their response. Out of the 125 respondents on Table 3 (not shown here), revealed that 52\% agrees that there is opportunity for taxpayers to complain about unfair tax assessment, $36 \%$ of the respondents disagree with the statement, while the remaining $12 \%$ did not answer at all. Table 3 (not shown here) also revealed that out of the 125 respondents that made up the sample, $73.6 \%$ of them disagreed with the statement that it is easier to identify taxpayers and income tax to be assessed to tax, $20.8 \%$ agreed with the statement while the remaining $5.6 \%$ were undecided. Analysis from Table 3 (not shown here) further revealed that $46.4 \%$ of the sample stated that the tax assessment method does not encourage voluntary enrolment into the tax net, $7.2 \%$ of the sampled respondents were undecided while the remaining $46.4 \%$ of the sample are of the view that the tax assessment method encourage voluntary enrolment into the tax net.

\section{Test of Hypothesis}

$\mathrm{H}_{01}$ : Personal Income Tax Assessment method in the rural communities does not encourage voluntary enrolment into the tax net. 


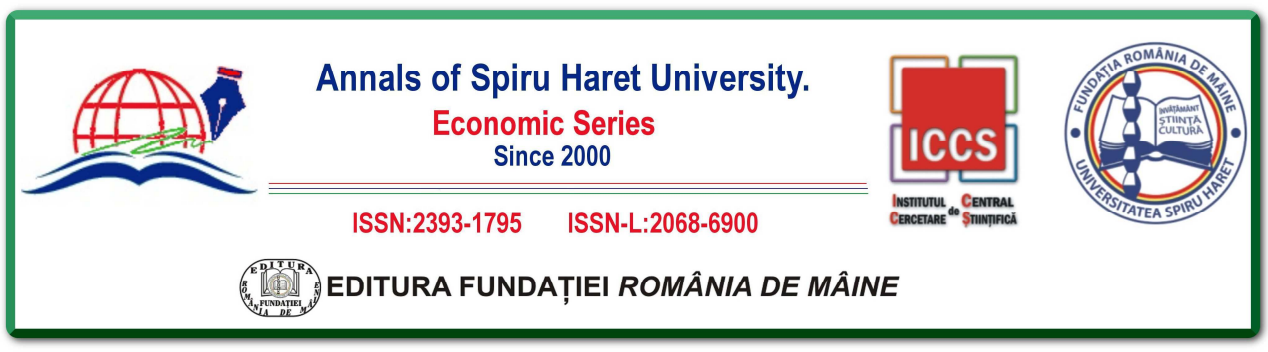

Issue 2/2018

It can be seen from the hypothesis one that there are two variables of interest, namely: assessment method and voluntary enrolment into the tax net. In order to ascertain if there is a significant relationship between the two variables, the Pearson moment correlation was carried out and the result is presented in the Table 4.

Table no. 4. Correlations between Method of Tax Assessment and Voluntary Enrolment

\begin{tabular}{|lc|c|c|}
\hline & $\begin{array}{c}\text { Method of Tax } \\
\text { Assessment }\end{array}$ & $\begin{array}{c}\text { Voluntary enrolment } \\
\text { into the tax net. }\end{array}$ \\
\hline Method of tax assessment & $\begin{array}{c}.955^{* *} \\
\text { Pearson Correlation } \\
\text { Sig. (2-tailed) } \\
\mathrm{N}\end{array}$ & 1 & .000 \\
& 125 & 1 \\
\hline Voluntary enrolment into & Pearson Correlation & $.955^{* *}$ & 125 \\
tax net & Sig. (2-tailed) & .000 & 125 \\
\hline
\end{tabular}

Source: Authors' Survey, 2017

The Table 4 shows that the correlation coefficient of the two variables is 0.955 which indicates that there is a strong and positive relationship between the two variables. Table 5 (not shown here) shows that a relationship exists between the independent variable (method of tax assessment) and the dependent variable (voluntary enrolment into the tax net). This is depicted from the coefficient of correlation value of 0.955 . The model indicates that there is significant coefficient of determination (R-Square) of 0.912 , which suggests that $91.2 \%$ of the variations in voluntary enrolment into the tax net would be explained by the method of tax assessment.

\section{Regression analysis of method of tax assessment and voluntary} enrolment

The regression analysis of tax assessment method and voluntary enrolment into the tax net is shown in the subsequent Tables.

Table no. 6. ANOVA ${ }^{b}$ 


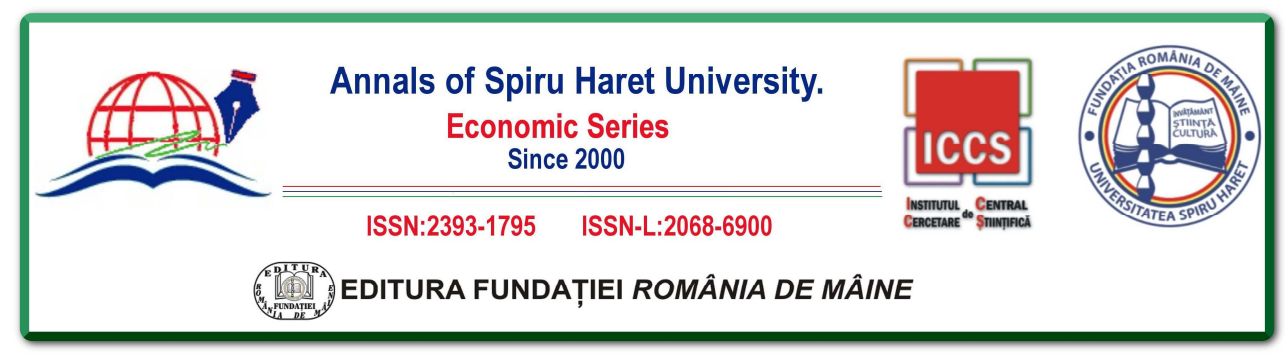

Issue 2/2018

\begin{tabular}{|ll|c|c|c|c|c|}
\hline & Model & Sum of Squares & Df & Mean Square & F & Sig. \\
\hline 1 & Regression & 296.621 & 1 & 296.621 & 1276.609 & $.000^{\mathrm{a}}$ \\
& Residual & 28.579 & 123 & .232 & & \\
& Total & 325.200 & 124 & & & \\
\hline
\end{tabular}

a. Predictors: (Constant), Method of Tax Assessment.

b. Dependent Variable: Voluntary enrolment into the tax net.

Source: Authors' Survey, 2017

Table 6 indicates that the analysis of variance of the fitted regression equation is significant with $\mathrm{F}$ value of 1276.609 . This is an indication that the model is a good one. Since the p-value is less than 0.05 , it shows a statistically significant relationship between the variables at 95 per cent confidence level.

Research Question 2: How effective are the methods of collection of Personal Income Tax in the rural communities for optimum tax revenue?

The influence of effective methods of collection on optimum tax revenue in the rural communities was considered, using the responses of the sample to the items that pertain to the questions. In order to answer research question two (2), questionnaire items: 10, 11, 12 and 13 were as analysed in Table 7 (not shown here). From the Table 7 (not shown here), it was revealed that $74.4 \%$ of the samples agree that the collection methods are secured and convenient for taxpayers, $23.2 \%$ disagree, while the remaining $2.4 \%$ did not answer the question. Out of the 125 respondents on Table 7 (not shown here), 57.6\% agree that banks, point of sales and automated teller machine cards are used in collection process, $16.8 \%$ of the respondents are undecided, while $25.6 \%$ disagree with the statement. Table 6 (not shown here) shows that $62.4 \%$ of the samples agree that tax officials do not encourage cash collection from taxpayers in the rural communities, $20 \%$ of the respondents think otherwise, while the remaining $17.6 \%$ of the sample did not answer the question. The Table 6 (not shown here) revealed that $60.8 \%$ of the sample respondents agreed that the blockage of revenue leakages through bank collection method, ensure optimum collection of tax revenue, $28.8 \%$ of the sample respondents disagree, while the remaining $10.4 \%$ of the sample were undecided.

Test of Hypothesis

$\mathrm{H}_{02}$ : Personal Income Tax collection methods in the rural communities are not effective for optimal tax revenue. 


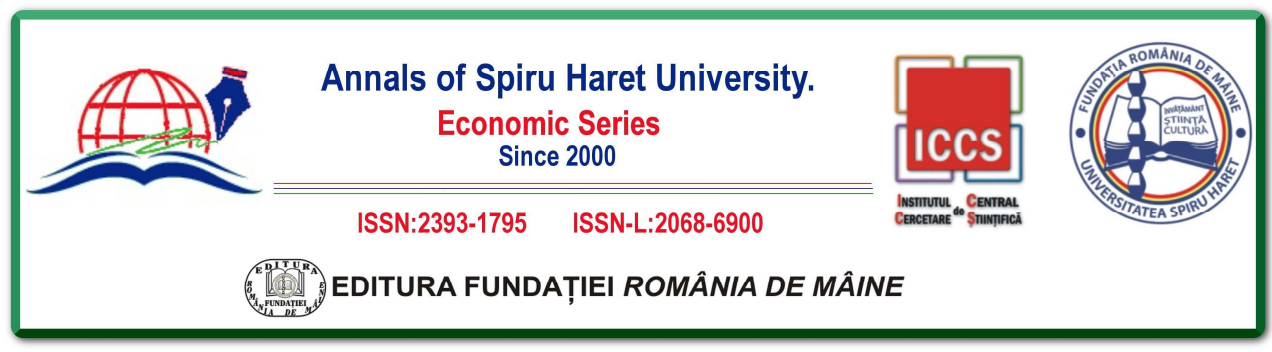

Issue $2 / 2018$

This hypothesis considers the influence of the collection methods on the optimal tax revenue. In order to ascertain if there is a significant relationship between the two variables the Pearson moment correlation was carried out and the result is presented in the Table 8 .

Table 8 shows that the correlation coefficient of the two variables is 0.657 . This indicates that there is a strong and positive relationship between the dependent and the independent variables.

Table no. 8. Correlation between Collection Methods and Optimal Tax Revenue

\begin{tabular}{|lc|c|c|}
\hline & & $\begin{array}{l}\text { Collection } \\
\text { Methods }\end{array}$ & $\begin{array}{c}\text { Optimal Tax } \\
\text { Revenue }\end{array}$ \\
\hline Collection Methods & Pearson Correlation & 1 & $.657^{* *}$ \\
& Sig. (2-tailed) & & .000 \\
& $\mathrm{~N}$ & 125 & 125 \\
\hline Optimal tax revenue & Pearson Correlation & $.657^{* *}$ & 1 \\
& Sig. (2-tailed) & .000 & 125 \\
& $\mathrm{~N}$ & 125 & \\
\hline
\end{tabular}

Source: Authors' Survey, 2017

Regression analysis of collection methods and optimal tax revenue

Table no. 9. ANOVA

\begin{tabular}{|ll|c|c|c|c|c|}
\hline & Model & Sum of Squares & Df & Mean Square & F & Sig. \\
\hline 1 & Regression & 107.587 & 1 & 107.587 & 93.447 & $.000^{\mathrm{a}}$ \\
& Residual & 141.613 & 123 & 1.151 & & \\
\cline { 2 - 5 } & Total & 249.200 & 124 & & & \\
\hline
\end{tabular}

a. Predictors: (Constant), Collection Methods.

b. Dependent Variable: Optimal tax revenue.

Source: Authors' Survey, 2017

Research Question 3: How effective and efficient can the Relevant Tax Authorities apply the Personal Income Tax Laws in the rural communities?

44 


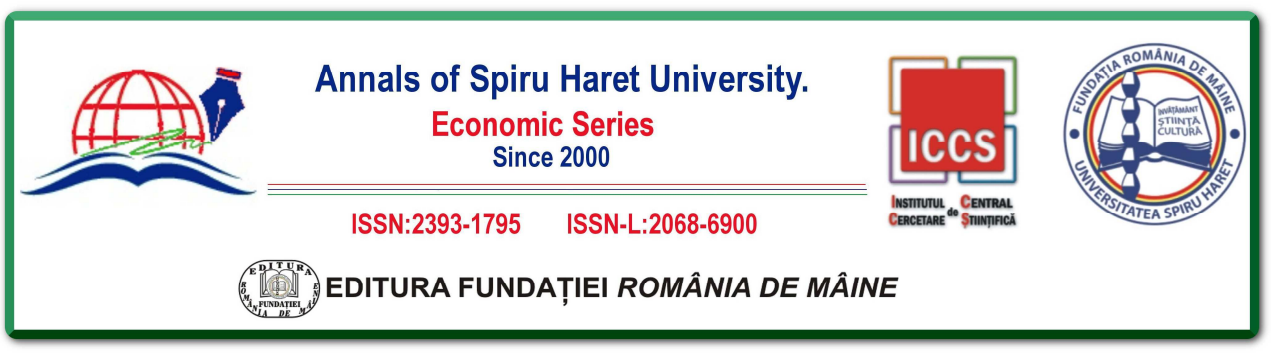

Issue 2/2018

The influence of effective and efficient relevant tax authorities on application of Personal Income Tax Laws in the rural communities was considered using the responses of the sample to the items that pertain to the questions. In order to answer the research question, four (4) questionnaire items 14, 15, 16 and 17 were as analysed in Table 10 (not shown here).

\section{Test of Hypothesis}

$H_{03}$ : The relevant tax authorities are not effective and efficient in applying the Personal Income Tax Laws in the rural communities.

This hypothesis considers the influence of effective and efficient relevant tax authorities on Personal Income Tax Law application in the rural communities. Pearson moment correlation was carried out in order to ascertain if there is a significant relationship between the two variables and the result is presented in the Table 11.

Table no. 11. Correlation between Effective and Efficient RTA and PITA Application in the Rural Communities

\begin{tabular}{|c|c|c|}
\hline & $\begin{array}{l}\text { Effective and } \\
\text { efficient relevant } \\
\text { tax authorities }\end{array}$ & $\begin{array}{l}\text { PITA application in } \\
\text { the rural } \\
\text { communities }\end{array}$ \\
\hline $\begin{array}{ll}\text { Effective and efficient } & \text { Pearson Correlation } \\
\text { relevant tax authorities } & \text { Sig. (2-tailed) } \\
& \mathrm{N}\end{array}$ & $\begin{array}{c}1 \\
125\end{array}$ & $\begin{array}{l}.218^{*} \\
.015 \\
125\end{array}$ \\
\hline $\begin{array}{l}\text { PITA application in the Pearson Correlation } \\
\text { rural communities } \\
\text { Sig. (2-tailed) } \\
\text { N }\end{array}$ & $\begin{array}{l}.218^{*} \\
.015 \\
125\end{array}$ & 125 \\
\hline
\end{tabular}

*Correlation is significant at the 0.05 level (2-tailed).

Source: Authors' Survey, 2017

The Table 11 shows that the correlation coefficient of the two variables is 0.218 which indicates that there is a positive relationship.

Regression Analysis of Effective and Efficient Relevant Tax Authorities on the Application of PITA in Rural Communities 


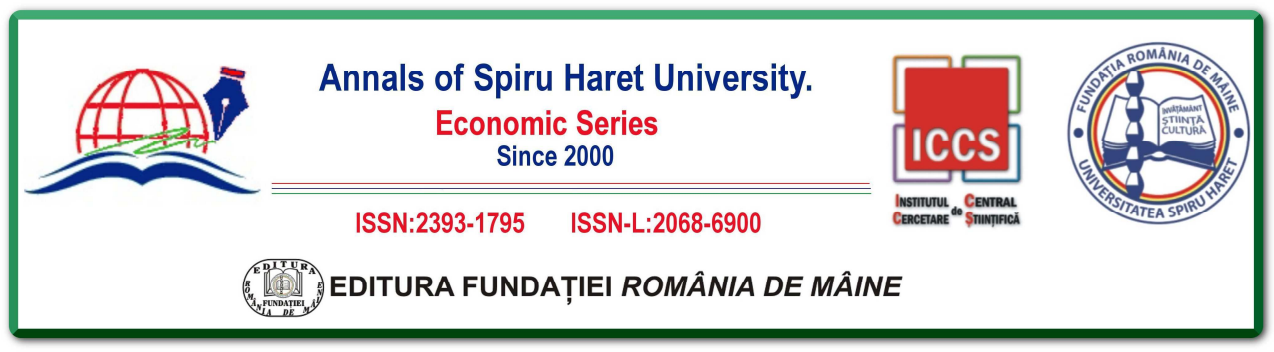

Issue 2/2018

Table no. 12. ANOVA ${ }^{b}$

\begin{tabular}{|ll|c|c|c|c|c|}
\hline & Model & Sum of Squares & Df & Mean Square & F & Sig. \\
\hline 1 & Regression & 9.988 & 1 & 9.988 & 6.117 & $.015^{\mathrm{a}}$ \\
& Residual & 200.844 & 123 & 1.633 & & \\
Total & 210.832 & 124 & & & \\
\hline
\end{tabular}

a. Predictors: (Constant), Effective and efficient relevant tax authorities.

b. Dependent Variable: PITA application in rural communities.

Source: Authors' Survey, 2017

Table 12 tests the significant relationship between the independent and dependent variables. Given the asymptotic significance of 0.015 , this value is less than the decision criterion value of 0.05 ; therefore the null hypothesis is rejected and the alternative hypothesis which states that the relevant tax authorities are effective and efficient in applying the Personal Income Tax Laws in the rural communities is accepted.

\section{Multiple Regression Analysis}

Multiple regressions analysis was also carried out in respect of hypotheses 13 , and the results were as analysed in Tables 13 to 15 .

Table no. 13. Model Summary

\begin{tabular}{|c|c|c|c|c|}
\hline Model & $\mathrm{R}$ & R-Square & $\begin{array}{c}\text { Adjusted R- } \\
\text { Square }\end{array}$ & Std. Error of the Estimate \\
\hline 1 & $.663^{\mathrm{a}}$ & .439 & .425 & .813 \\
\hline
\end{tabular}

a. Predictors: (Constant), Enforcement/taxpayers enlightenment education, method of tax assessment and collection/payment methods.

Source: Authors' Survey, 2017

$\mathrm{R}$ column represent the multiple correlation coefficient, which is one measure of the quality of the prediction of the dependent variable. $R$ value of 0.663 indicates a good level of prediction. $R$ Square $\left(R^{2}\right)$ at 0.439 explains that $43.9 \%$ of the variance in the dependent variable (PITA application in rural communities) is attributable to the influence of independent variables (enforcement/taxpayers enlightenment education, method of tax assessment and collection/payment methods). 


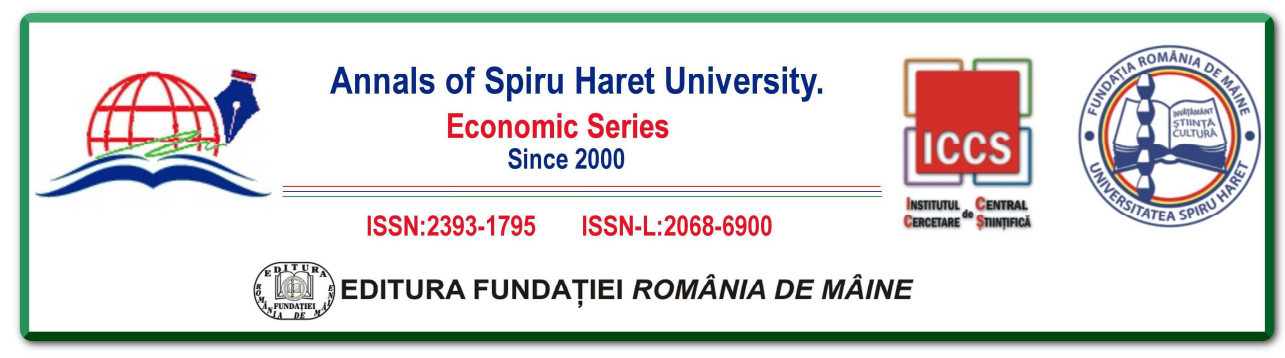

Issue 2/2018

Table no. 14. ANOVA ${ }^{b}$

\begin{tabular}{|ll|c|c|c|c|c|}
\hline & Model & Sum of Squares & Df & Mean Square & F & Sig. \\
\hline 1 & Regression & 62.591 & 3 & 20.864 & 31.587 & $.000^{\mathrm{a}}$ \\
& Residual & 79.921 & 121 & .661 & & \\
& Total & 142.512 & 124 & & & \\
\hline
\end{tabular}

a. Predictors: (Constant), Enforcement/taxpayers enlightenment education, method of tax assessment and collection/payment methods.

b. Dependent Variable: PITA application in rural communities.

Source: Authors' Survey, 2017

The ANOVA Table 14 shows the overall significant relationship between the independent and dependent variables. With the value of the $\mathrm{F}$ test $(3,121)=$ 31.587 , and given the asymptotic significance of 0.000 , this value is less than significant value of 0.05 ; therefore we say a relationship exists between the variables of enforcement of tax law on defaulters/taxpayers enlightenment education, method of tax assessment and collection/ payment methods.

Table no. 15. Coefficients

\begin{tabular}{|l|l|c|c|c|c|c|}
\hline \multirow{3}{*}{ Model } & & \multicolumn{2}{|c|}{$\begin{array}{c}\text { Unstandardized } \\
\text { Coefficients }\end{array}$} & $\begin{array}{c}\text { Standardized } \\
\text { Coefficients }\end{array}$ & \\
\hline & & B & Std. Error & Beta & T & Sig. \\
\hline 1 & (Constant) & 1.159 & 0.238 & & 4.871 & 0.000 \\
& Method of tax assessment & -0.418 & 0.059 & -0.558 & -7.085 & 0.000 \\
& Collection/payment methods & 0.316 & 0.065 & 0.401 & 4.834 & 0.000 \\
& Enforcement and taxpayers & 0.207 & 0.065 & 0.242 & 3.189 & 0.000 \\
& enlightenment education & & & & & \\
\hline
\end{tabular}

a. Dependent Variable: PITA application in rural communities.

Source: Authors'Survey, 2017

Since the simple linear regression is written $y=a+b x$, where $y$ is the dependent variable, ' $a$ ' is the constant, ' $b$ ' is the regression coefficient and $x$ is the independent variable. The $\mathrm{p}$-value of both constant and independent values being 0.000 means that the value for the regression equation that significantly influence Personal Income Tax Administration in the rural communities is $\mathrm{y}=1.159+$ $0.418 \mathrm{x}_{1}+0.316 \mathrm{x}_{2}+0.207 \mathrm{x}_{3}$. Beta (Standardized Coefficients); because of its weights and co-linearity, it expresses the relative importance of each independent 


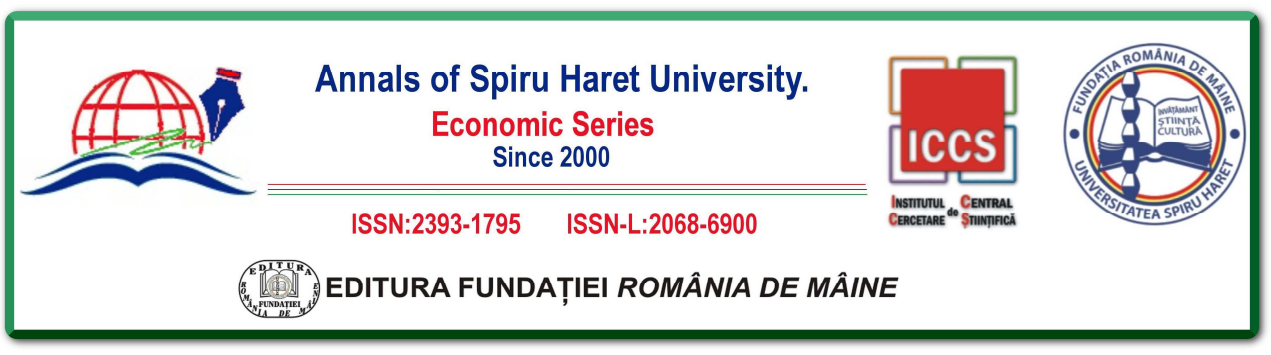

Issue $2 / 2018$

variables in a standardized terms. Both independent variables are significant predictors and also show that collection/payment methods have a higher impact than enforcement/taxpayers enlightenment education and method of tax assessment. (Beta $=0.401,0.242$ and Beta -0.558$)$.

\section{SUMMARY, CONCLUSION AND RECOMMENDATIONS}

\section{Summary of Findings}

This study was conducted to investigate the problems associated with Personal Income Tax Administration in the rural communities and proffer possible solution to the problems. Six Local Government Areas in Ogun State, Nigeria were selected for the study. The findings revealed that there is a relationship between Personal Income Tax assessment method in the rural communities and voluntary enrolment into the tax net. It also revealed that there is a relationship between the collection/payment methods and optimal tax revenue; and that the efficiency and effectiveness of the relevant tax authorities has significant impact on the application of Personal Income Tax in the rural communities. Other findings include the opportunity afforded the taxpayers to complain about unfair tax assessment. Availability of Banks, Point of Sales (POS) and the use of Automated Teller Machine (ATM) in the process of collection/payment of tax assessed. This ensures blockage of tax revenue leakages, thereby giving confidence to the rural taxpayers that their taxes actually get into government's coffer. Regular enforcement of tax laws on defaulters and taxpayers' enlightenment education justified the effectiveness and efficiency of tax officials as they appear to be competent and having adequate knowledge about Personal Income Tax Administration.

\section{Conclusion}

The findings of the study among others indicate that there is a relationship between administration of Personal Income Tax and rural communities. It shows that an efficient tax assessment method is one of the prerequisite that can support voluntary enrolment into the tax net. The challenge observed in the course of the study is the need to always ensure that taxpayers are given adequate opportunity to complain and express their view, which is provided for by the Personal Income Tax law and also in consonant with the mission statement of OGIRS: "To help the taxpayers understand and meet their tax responsibilities, by providing efficient top 


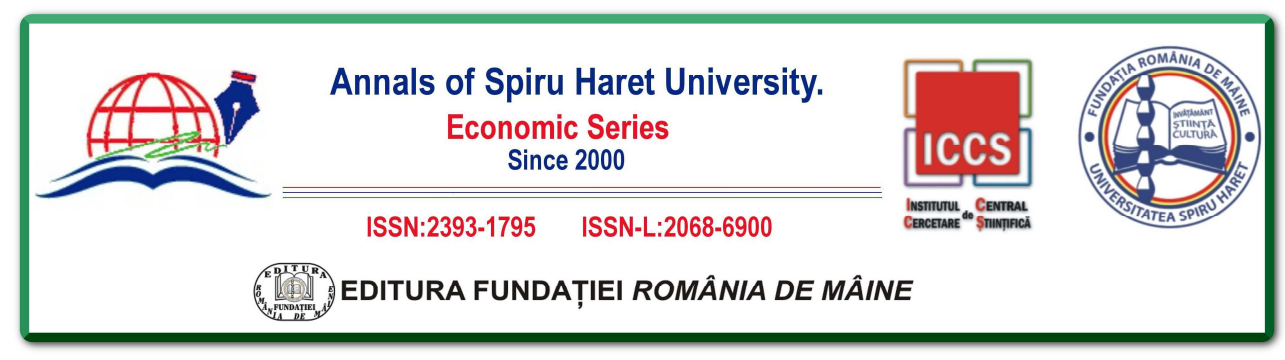

Issue 2/2018

quality service and applying the tax laws with integrity and fairness to all". Using commercial banks, micro finance banks, point of sales and automated teller machine in the collection methods proved to be successful. The multiple regression equation shows that the banks and other alternative methods of collections have significant impact on optimal tax revenue. Engagement and deployment of competent and carrier tax officers to manage the rural tax offices impacted significantly on the efficiency and effectiveness of the relevant tax authorities. The study revealed that tax inspectors attaches significance to enforcement of tax law on defaulters and taxpayers enlightenment education, since it will help to grow tax revenue and improve the knowledge of the taxpayers in the administration of Personal Income Tax. This paper contributes to knowledge by comprehensively analysing the combined effect of tax administration, policies and laws in Nigeria and thus filling the gap in literature between what the people perceive to be reliable tax revenue administration and what it is in reality. This study used six local government areas in Ogun State, Nigeria, it might be necessary for future research in this area of study by researchers to explore more local governments in Ogun State or even possibly extend the study to more local government areas in other States of Nigeria for more robust and more embracing results.

\section{Recommendations}

Based on the findings of the study, the following are recommended:

(i) Taxpayers in the rural communities need to be educated on the importance of performing their civic responsibilities through an effective means of communication.

(ii) The government should carried out an enlightenment programmes which may include award for the recognition of the best rural taxpayers, not necessarily by financial reward, but through letter of commendation and recognition, which will further elicit competition among the taxpayers and cooperation with the relevant tax authorities.

(iii) An important finding of this research pertains to the fact that tax officials do not encourage cash payment / collection, thereby retaining the confidence of the rural taxpayers that all tax payments goes into government coffers. If other innovative methods of collection and payment for example, the use of tax recharge card via mobile phone in collaboration with mobile network providers are 


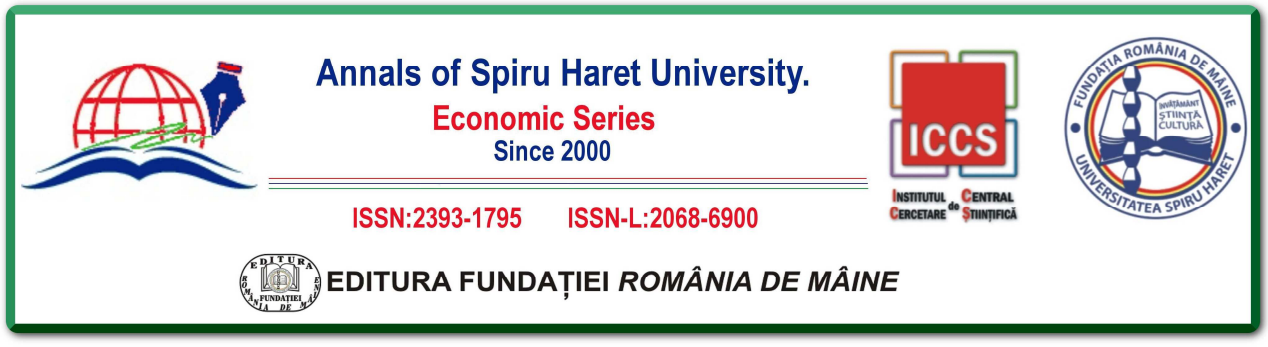

Issue 2/2018

implemented, there may be a great improvement in tax revenue, in view of the fact that mobile phone is widely used in the rural communities.

(iv) It is also recommended that training and retraining programmes be put in place to equip tax officials in the rural communities on what it takes to be an effective and efficient tax administrator.

\section{References}

Abiola, J. I., "The Informal Sector and Tax Compliance in Nigeria," Journal of Administrative Studies, 11(3), (2007): 88-92.

Abiola, S., "Multiplicity of Taxes in Nigeria: Issues, Problems and Solutions," International Journal of Business and Social Science, 3 (17), (2012): 229-236.

Adams, S., The Wealth of Nations (London: Everyman's Library Ltd., 1910).

Adebisi, J. F. \& Gbegi, D. O., "Effect of Tax Avoidance and Tax Evasion on Personal Income Tax Administration in Nigeria," American Journal of Humanities and Social Sciences, 1 (3), (2013): 125-134.

Adeyeye, G. B., The Impact of Taxpayers' Perception of Good Governance on Voluntary Tax Compliance in Lagos State, Nigeria (Unpublished Thesis, Department of Accounting, University of Lagos, Nigeria, 2013).

Adeyeye, G. B., "Tax as a Stimulus for Economic Growth and Development in Nigeria," Nigerian Journal of Management Studies, 10(1), (2009): 192-215.

Angahar, P. A. \& Alfred, S. I., "Personal Income Tax Administration in Nigeria: Challenges and Prospects for Increased Revenue Generation from Self-Employed Persons in Persons in the Society," Global Business and Economics Research Journal, 1 (1), (2012): 1-11.

Ariwodola, J. A., Personal Taxation in Nigeria: including capital gains tax $\left(4^{\text {th }}\right.$ ed.), (Festac Town: JAA Nigeria Limited, 2001).

Asada, D., "The Administration of Personal Income Tax in Nigeria: Some Problems Areas," Working Paper (University of Jos, 2005).

Ayodele, O., "Tax Policy Reforms in Nigeria," United Nation University-World Institute for Development Economics Research (UNU-WIDER). Research Paper No. 2006/03, (2006): 1-43.

Ayua, I. A., Nigerian Tax Law (Ibadan: Spectrum Law Publication, 1996).

Barkoczy, S., "The Nature of an Income Tax Assessment," Journal of Australian Taxation, 36 (1999). 


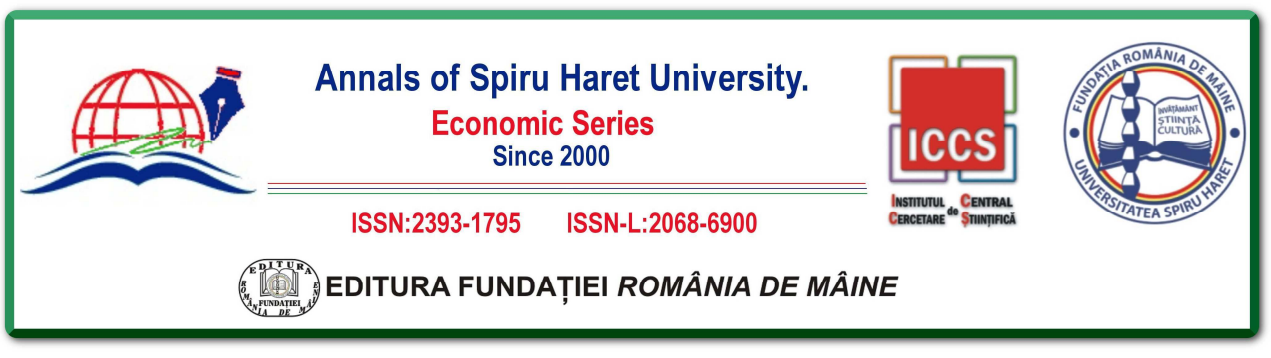

Issue 2/2018

Civil Society Legislative Advocacy Centre (2014). Expanding the tax base in the Nigerian informal sector. Retrieved from http://www.maketaxfair.net/assets/policy-brief-oninformal-sector.pdf

Dike, M. A., "Subject Your Incomes to Tax Assessment and Payment, CITN Advises Professionals," Chartered Institute of Taxation of Nigeria, Press release (2014).

Dube, G., "Informal Sector Tax Administration in Zimbabwe," Public Administration and Development, 34, (2014): 48-62.

Government of South Africa, "Delivering Municipal Services in Rural Areas: The Rural Development Framework Definition of Rural Areas," South African Journal on Rural Development Framework, (1997): 191-210.

Emory, L. W. \& Cooper, D. R., Business research methods (4 ${ }^{\text {th }}$ ed.), (Illinois: Richard Doyen Publishers, 1991).

Federal Ministry of Finance, National Tax Policy (The Federal Government Printer, Lagos, Nigeria, 2016).

Federal Republic of Nigeria Official Gazette, Personal Income Tax (Amendment) Act, 2011.

Federal Republic of Nigeria, Personal Income Tax Act, CAP P8 Law of Federation Federation of Nigeria (LFN), 2004.

Federal Republic of Nigeria, Taxes and Levies (Approved List for Collection) Act, 1998, No. 21, Part I-III.

Ilaboya, O. J., "Taxation and the Nigerian Informal Sector," Journal of taxation and Economic Development, 13 (1), (2014): 60-75.

Industrial/Organisational Solutions, "Guidelines for Criterion-related Validation Studies," Industrial/Organisational Solution Inc. White Paper 012 (2010).

Joint Tax Board, "Administration of Personal Income Tax and Taxes and Levies Collectible by the Three Tiers of Government in Nigeria," The Punch, December 3, (2012): 85.

Joshi, A. \& Ayee, J., Associational Taxation: A Pathway into the informal sector? (Cambridge: Cambridge University Press, 2007).

Kiabel, D. B. \& Nwokah, G. N., Boosting revenue generation by State Journal of Sciences, 8 (4), (2009). Retrieved from: http://www.proquest.com/.

Lekan, S. \& Sunday, O., Taxation, Principles and Practice in Nigeria (Ibadan, Silicon Publishing Company, 2006).

Leyira, C. M., Chukwuma, E. \& Asian, A. U., "Tax System in Nigeria - Challenges and the Way Forward," Research Journal of Finance and Accounting, 3, (5), (2012): 9-15.

Mengesha, Y. \& Ashebir, Z., "Assessing the Gaps and Problems That Exist Between the Business Community and Tax Authorities of Dire Dawa Administration," Developing Country Studies, 3, (9), (2013): 167-173.

Mustapha, I., "Strategies for Improving State Revenue Generation," JTB News, A quarterly magazine of the Joint Tax Board of Nigeria, 1 (2) (2006). 


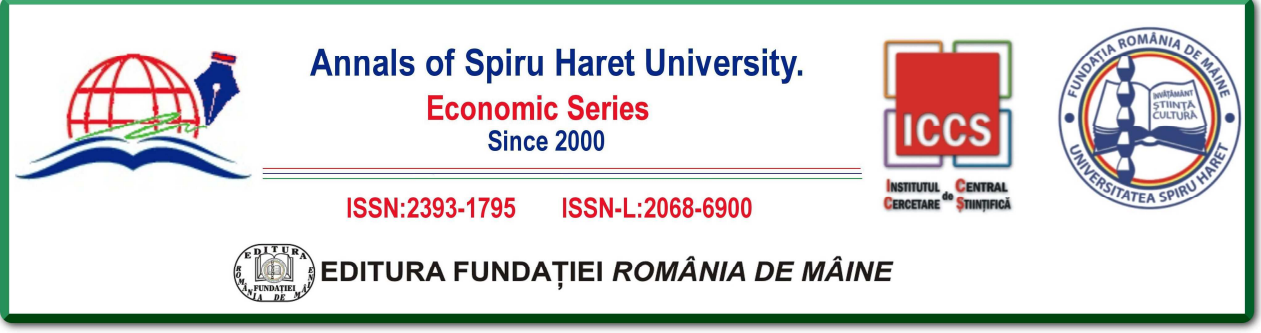

Issue $2 / 2018$

Nzotta, S. M., "Tax Evasion Problems in Nigeria: A Critique," The Nigerian Accountants, 40 (2), (2007): 40-43.

Ogun State Government - Ogun State Internal Revenue Service, Central Department of Statistics, Projected Census \& Internal Revenue Service Tax Offices in Local Government Areas of Ogun State, Nigeria (2014).

Omoigui, I., Emerging Issues in Tax Administration: The Way Forward for Nigeria. Paper presented at the $4^{\text {th }}$ National Conference of the Department of Finance, University of Lagos, Nigeria $12^{\text {th }}$ July 2011.

Prichard, W., "The Policies of Taxation and Implications for Accountability in Ghana, 19812008," IDS Working Paper 330 (Brighton, Institute of Development Studies, 2009).

Roscoe, J. T., Fundamental Research Statistics for the Behavioural Sciences (2 $2^{\text {nd }}$ ed.), (New York: Holt Rinehart and Winston, 1975).

Soyode, L. \& Kajola, S. O., Taxation Principles and Practice in Nigeria ( $1^{\text {st }}$ ed.), (Ibadan: Silon Publishing Company, 2006).

Uremadu, S. O. \& Ndulue, J. C., "A Review of Private Sector Tax Revenue Generation at Local Government Level: Evidence from Nigeria," Journal of Public Administration and Policy Research, 3 (6), (2011): 174-183.

Yerokun, O., Nigeria Revenue Law Report (NRLR Part1) (Lagos: Nigerian Revenue Project Publication, 1997). 